\title{
Students' use behavior towards e-learning tools during COVID- 19 pandemics: Case study of higher educational institutions of Thailand
}

\author{
Chaiyawit Muangmee ${ }^{1}$, Sebastian Kot ${ }^{2}$, Nusanee Meekaewkunchorn ${ }^{3}$, Nuttapon Kassakorn ${ }^{4}$, Somyos \\ Tiranawatananun ${ }^{5}$, Bilal Khalid ${ }^{6}$ \\ 1,3,4,5Faculty of Management Science, Bansomdejechaopraya Rajabhat University, Bangkok, Thailand \\ ${ }^{2}$ Faculty of Management, Czestochowa University of Technology, Czestochowa, Poland \\ ${ }^{2}$ Faculty of Economic Sciences and IT, North-West University, Vaal Triangle, South Africa \\ ${ }^{6}$ KMITL Business School, King Mongkut's Institute of Technology Ladkrabang, Bangkok, Thailand
}

\section{Article Info}

Article history:

Received Feb 27, 2021

Revised Aug 6, 2021

Accepted Sep 8, 2021

\section{Keywords:}

Higher educational institutions Intention

Learning value

Pandemic period

Social distancing

UTAUT2 model

\begin{abstract}
The research purpose was to conduct an empirical investigation into students' use behavior of e-learning tools during the COVID-19 pandemic, a case study of higher educational institutions in Thailand. The study applied the UTAUT2 theoretical model. Primary data was collected using a structured questionnaire from a total of 1,493 students across institutions of higher learning in Thailand. Structural equation modelling (SEM) was conducted using AMOS. The findings indicated that student's behavioral intention to use e-learning tools is positively and significantly influenced by performance expectancy $(\beta=0.22, \quad p<0.05)$; effort expectancy $(\beta=0.14$, $p<0.05)$; social influence $(\beta=0.20, p<0.05)$; facilitating condition $(\beta=0.50$, $p<0.05)$; hedonic motivation $(\beta=0.35, p<0.05)$; learning value $(\beta=0.51$, $\mathrm{p}<0.05)$; and social distance $(\beta=0.46, \mathrm{p}<0.05)$. Similarly, behavioral intention by the students to use e-learning tools have a positive and significant effect on actual use of e-learning tools $(\beta=0.82, \mathrm{p}<0.05)$. Learning value and social distance had the largest positive effects on the student's behavioral intention to use e-learning tools. It is important for the higher education institutions in Thailand to consider them. They are major factors driving students towards adopting e-learning tools during disruptions as witnessed during the COVID19 pandemic period.
\end{abstract}

This is an open access article under the CC BY-SA license.

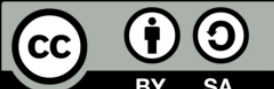

\section{Corresponding Author:}

Sebastian Kot

Faculty of Management

Czestochowa University of Technology

Generała Jana Henryka Dąbrowskiego 69, Częstochowa, Poland

Email: sebastian.kot@wz.pcz.pl

\section{INTRODUCTION}

War, pandemics, epidemics are some of the leading factors that have reshaped the world's usual working and learning mechanisms and have also played their part the need for innovations and inventions that circumvent such disruptions. By definition, a pandemic is an occurrence of an illness that arises over an extensive terrestrial region and affects an unusually large percentage of the population. The last time a pandemic arose was swine flu in 2009, which experts believe killed thousands of people. Pandemics are probable if a virus is new and may infect people effortlessly and can escalate from person-to-person in a proficient and continued manner. The COVID-19 virus in 2020 which has caused a global disruption of 
businesses, schools, and global movements seems to tick all these boxes and with no known medical cure yet, and the vaccines still in development and gradually being rolled out to contain its spread [1]-[3].

Different organizations and countries are developing proactive strategies, policies, frameworks, and disaster management protocols to cope with the restrictions on movement and businesses created by the outbreak and spread of COVID-19 pandemic, especially the mass gathering of people in one location like in schools, offices, and restaurants. Similarly, Thailand mirroring the global pattern has also taken some measures to combat the spread of COVID-19 by the deployment of infrastructure, based on information and communication technology (ICT). ICTs have not only changed the working and learning habits of the workers but have also reshaped the size and structure of the organizations, industries, and educational institutions. Most businesses have gone remote, educational institutions, around the globe also adopted ICTs, at schools, colleges, and universities for learning and sharing of knowledge to continue through online learning. Countries with good ICT infrastructure and robust online learning management system are operating their services industries including education smoothly, while those with a poorly developed infrastructure are working hard to conform to the new normal.

Unfortunately, the world has been traumatized by the impact of the pandemic which has created severe consequences on the personal lifestyles of individuals, their social living, and global economy as we know it. The World Health Organization (WHO) reported about 90,893 confirmed cases and 3,110 deaths as of March 3, 2020 [4]. On May 3, 2021, the estimates had increased exponentially to 153.5 million confirmed cases and over 3.2 million deaths and counting since the first recorded outbreak in Wuhan City, China [5]. In order to contain the spread of the COVID-19 virus, most governments around the globe momentarily closed learning institutions. According to the United Nations, more than 1.4 billion students in 136 nations were affected by the shuttering of schools and universities to avoid the spread of COVID-19. These statistics are bound to rise unless a cure or vaccines are manufactured to forestall the massive educational disturbance of schools, colleges, and universities around the globe [6]-[9]. It was, therefore, creditable for the Thailand government to shut down schools and universities much before nations like Italy and the UK. It unfortunately has now appeared as the new worldwide focal point of the virus. This was because at first the UK and Italy hesitated a bit. Thailand took pivotal action by confronting this new reality and realigning its priorities by turning to ICTs towards delivering education even with the lock down of schools.

Educational institutes around the globe are now conforming to the reality of online learning as a substitute for in-class learning. Thus, the need to update the educational policies that allow for changes in academic delivery and measuring learning outcomes and evaluation of the process is essential. While not thorough, such policy activities could comprise lessening the education load and re-examining pass measurements [10], [11]. Although learners are attracted to e-learning courses because they are perceived as being less rigorous than in-class learning, it should, however, not demand the online learning experience and online course quality [12], [13]. The volume of candidates, who leave the e-learning activity without completing the course of study, may be hard to relate with e-learning's effectiveness but surely it questions other related factors. One prominent factor is the fear towards technology adoption [14]. There could be many potential e-learning enthusiasts who may not actually start due to fear of not knowing how to apply the technology [15], or computer-based anxiety because of the newness of the activity [16].

Besides, technology acceptance in the case of learning may also vary from user to user. Traditionally online learning was not a mandatory requirement and solely discretionary for students whether to study at their convenience or attend classes visiting educational institution due to no formal academic consequence; however, due the outbreak of COVID-19 has seen e-learning being made a mandatory requirement for all students enrolled in online classes. Their attitude towards e-learning tools can be influenced by their use of the internet and other facilitating factors [17]. Understanding the attitude of students towards the adoption of e-learning would enable policymakers to determine: i) The students' behavioral intentions and actual use adoption of e-learning tools effectiveness; ii) What factors influence students' behavior intention to use e-learning tools?; iii) What factors influence students' actual use to adopt e-learning tools? [18]. The problem this study attempts to solve is to identify factors influencing the behavior intention and actual use of students for adoption of e-learning tools engaged by higher educational institutions of Thailand. Another concept that promoted the idea of online learning was the social distance requirement to mitigate the spread of COVID-19. There is few to no data on how it has influenced e-learning or not in the context of Thailand.

Thus, the problem this study addressed was students' use behavior towards e-learning tools during COVID-19 pandemic. The reason is to understand motivations and inhibitions towards the use of e-learning platforms by students and how they coped with the lock down situation when educational institutions were closed in most places to mitigate the spread of the virus. This is because accepting a new technology is challenging; prior studies on e-learning tools show significant results in the adoption of behavioral intention and actual use [19]-[21]. Unified Theory of Acceptance and Use of Technology 2 (UTAUT 2) model was 
introduced by Venkatesh, et al. [22], they called for additional constructs to increase its predictive power. Previous investigation was on the spontaneity of social distancing in response to the simultaneous epidemic under a virtual experiment [23]. Hence, this study adds social distancing to the UTAUT2 independent variables, expecting it adds to the predictive power of UTAUT2 while measuring students' behavioral intentions and actual use to adopt e-learning tools. Previous studies [8], [24], [25] have purely relied on the dimensions of UTAUT2 - performance expectancy (PE), effort expectancy (EE), social influence (SI), facilitating conditions (FC), hedonic motivation (HM), learning value (LV), and social distancing (SD).

The novelty in this study is the addition of social distancing variable, as per the existing literature, no study has considered the effect of social distancing on the students. Hence, the research study expects it to positively affect users' behavioral intention and actual use of e-learning platforms. In general, this study adds one important variable, i.e., social distancing to the independent variables' list of UTAUT2, therefore extending the predictive power of UTAUT2.

The broader objectives of the study are to predict the viability of the UTAUT2 model in determining students behavioral intention and actual use of e-learning tools engaged by higher educational institutions of Thailand for tutoring students. The detailed sub-objectives are reported as:

i) To identify the relationship between performance expectancy and behavioral intention to use e-learning tools engaged by higher educational institutions of Thailand.

ii) To identify the relationship between effort expectancy and behavioral intention to use e-learning tools engaged by higher educational institutions of Thailand.

iii) To identify the relationship between social influence and behavioral intention to use e-learning tools engaged by higher educational institutions of Thailand.

iv) To identify the relationship between facilitating conditions and behavioral intention to use e-learning tools engaged by higher educational institutions of Thailand.

v) To identify the relationship between hedonic motivation and behavioral intention to use e-learning tools engaged by higher educational institutions of Thailand.

vi) To identify the relationship between learning value and behavioral intention to use e-learning tools engaged by higher educational institutions of Thailand.

vii) To identify the relationship between social distancing and behavioral intention to use e-learning tools engaged by higher educational institutions of Thailand.

viii) To identify the students behavioral intention and actual use of e-learning tools engaged by higher educational institutions of Thailand.

Theoretically, this study is expected to produce diversified implications which add to the body of knowledge about UTAUT2 and e-learning as well as several guidelines for policymakers as well as contributing to the general literature on UTAUT2. Most studies centering on UTAUT2 focuses on general perspective of technology adoption. This study provides a perspective of e-learning tools adoption at higher educational institutions of Thailand, this further purifies and extends the generalizability of the model. In addition, responding to the postulations of Venkatesh, et al. [17], this study broadens the UTAUT2 model with the addition of social distancing as independent variables. Hence, this research provides a better outlook on the factors influencing students' behavioral intentions and actual use of adopting e-learning. The research study was conducted on students of higher educational institutions in Thailand and data was collected from those who enrolled for online courses during the COVID-19 pandemic shutdown of institutions. Previous studies [26]-[29] have already reported certain factors as contributing to users' intention to use new technology; hence, this study did not include students' interviews to identify more factors and only relied on the questionnaire instrument. In addition, the study only covered the perspective of e-learning tools engaged by higher educational institutions of Thailand during the COVID-19 pandemic restrictions in 2020 when COVID-19 virus began to spread.

This study includes seven independent variables of the UTAUT2 model, performance expectancy, effort expectancy, social influence, facilitating conditions, hedonic motivation, and learning value. In addition, to the mentioned variables, this study added social distancing of the students to the list of independent variables. Therefore, a total of seven independent variables were used to measure students' behavioral intention and actual use of e-learning tools (dependent variables of the UTAUT2 model). The study produced structural models based on the established hypothesized relationships.

In latest years, prompt progresses in technology and the web have led to many alterations in businesses [30] and education [31]. One of the most significant alterations in education is in the method of distance learning. Distance learning is used to describe learning where teachers and students are physically separated, this however, is not a new ideology; but developing technologies and the web permit web-based distance learning and consequently evaluated its status [32]. As an outcome of these improvements, many colleges have started to use web-based distance learning structures to deliver quality education that is free of time and place restrictions [33]. Online learning management systems are also referred as distance education, 
e-learning, and online learning, forms of education in which several technologies are used to simplify student-instructor and student-student contact. Distance learning was conventionally based on the concept of non-traditional learners, which include full-time workers, army personnel, and visitors or individuals in secluded areas who are not able to join classroom lectures [34].

In an online learning management system, practices from a regular class are taken and transformed into a virtual or remote-learning procedure based on educational pedagogy with the aim being to generate a remote-learning correspondence routine. The simplest manner to do this is to formulate a basic agenda of every class segregated in class periods like virtual meetings or conference-room meetings which is considered as an alternative of in-person meetings [35]. The last decade has seen a drastic adoption of elearning technologies or ICTs in the society as whole; this has also influenced the adoption of such technologies in education systems globally. Therefore, the aim of this research is to develop a theoretical framework based on a well-known of UTAUT2. The proposed model contributes to limited research in general perspective on e-learning tools in Thailand, and this research was conducted specifically from higher educational institutions of Thailand perspective to get insights and ascertain to measure student's behavioral intention and actual use of e-learning tools. The model is presented in depth in a separate section.

According to the United Nations Research Institute for social developments, social distancing implies the aspect of preventing, managing, and overcoming situations, which have adverse effects to the people's life and well-being. Social distancing is usually discussed in the context of adoption and implementation of programs, which are designed to reduce the exposure of people to conditions that have adverse effects to their lives, such as risks to infectious diseases, criminal activities, and natural calamities. It also focuses on enhancing their capacity to manage the social risks such as social exclusions, unemployment, sickness, disabilities, and old age [36]. In this study, social safety has been applied with regard to the mitigation of the spread of COVID-19 virus, an infectious disease caused by severe acute respiratory syndrome, coronavirus. The common symptoms include fever, cough, and shortness of breath [37]. Being an infectious disease, among the healthcare guidelines given for protection is maintaining social distance, stay at home and lockdown in some countries to prevent the spread of the virus. As a result, all the learning institutions have been closed as a precautionary measure to prevent the spread [38].

The mitigation strategy is e-learning, which is widely exercised by universities and educational institutions to deliver their courses to students online utilizing e-learning tools or online learning platforms. Various online platforms of e-learning tools are available to choose depending on the needs and requirements of the institution or online facilitator/lecturer having live engagement with students, delivering online learning and teaching resources. Some universities are delivering lectures to their students through their personalized online learning platform [39]. As a mitigation strategy, offering online courses utilizing elearning tools has become a necessity during this pandemic situation. Some of the educational institutions have open access to their courses, and collaborating with universities to deliver courses to students in an online pattern. There are four significant principled problems associated to emergent and recurring infectious sicknesses which include: the part and duties of health personnel; the costs of infectious illness to commerce amongst states; the test of giving impartial access to health-care; and the correspondence of individual rights versus public well-being. These four problems are considered to be vital, for example, during the first eruption of severe acute respiratory syndrome (SARS) in 2002-2003, an occurrence that accompanied in a new age of worldwide public health law. So, they were anticipated to have significance in any future emerging infectious virus outbreak [40].

\section{RESEARCH METHOD}

The aim of this study is to identify factors that influence students' behavioral intention towards adopting e-learning tools - a technology-based distance learning approach. Therefore, technology adoption becomes an integral part of the study framework. Scholars have suggested numerous theories and technology adoption models that explain users' behaviors. The current study adopted UTAUT2 to construct the conceptual model.

In an attempt to overcome the constraints and limitations of the Technology Adoption Model (TAM) and several others, Venkatesh, et al. [22] developed UTAUT2 integrating the perspective of consumer affect, automaticity, and monetary cost. Taking guidance from previous findings they merged a list of existing technology adoption models to produce a unified model. UTAUT focused more on the behavioral intentions and actual use of the user to adopt technology of any kind and type adding the perspective of consumer affect, automaticity, and monetary costs, and not only limited to the adaptation of mobile and information technology in their learning and working operations [41]. Due to versatility of the UTAUT2 model, it proved its applicability in different domains and has been extended to different walk of lives. UTAUT2 has same utility for the academia and has been used to measure the applicability and acceptability of the technology for e-learning [42], [43].

Students' use behavior towards e-learning tools during COVID-19 pandemics ... (Chaiyawit Muangmee) 
There are many theories and previous research findings, which highlight the acceptability and applicability of technology in individual, group, and organizational lives. Theory of planned behaviors talks about the behavioral aspects of the user's intentions and actual use of the technology in theory daily operations [44]. Similarly, Socio-Technology Theory focuses on the deployment of technology for effective and efficient production and operational processes [45]. Moreover, Organizational Theory and New Institutional Theory support the acceptance and applicability of information and communication technologies for sustainability, maintainability, and development [46], [47]. UTAUT2 model includes an important construct user's behavioral intention to use technology (e-learning tools in this study). Ajzen [48] argued that intensions capture motivating factors and influence behavior (use). They are signals of users' willingness to try and plans to exert efforts to truly perform the task. This construct is a reflection of attitude towards the behavior (TPB, DTPB, TRA) and motivation (extrinsic and intrinsic) (MM). This study examined the effects of PE, EE, SI, FC, HM, LV, and SD on users' behavioral intention and actual use to adopt e-learning tools. The following hypothesis were tested during the study. Based on the stated theories, premises, findings and linkages, the following hypothesis have been formulated to guide the study.

H1: Performance expectancy positively affects behavioral intentions to use e-learning tools.

$\mathrm{H} 2$ : Effort expectancy positively affects behavioral intentions to use e-learning tools.

H3: Social influence positively affects behavioral intentions to use e-learning tools.

H4: Facilitating conditions positively affects behavioral intentions to use e-learning tools.

H5: Hedonic motivation positively affects behavioral intentions to use e-learning tools.

H6: Learning value positively affects behavioral intentions to use e-learning tools.

H7: Social distancing positively affects behavioral intention to use e-learning tools.

H8: Behavioral intention positively affects the actual use of e-learning tools.

The constructs of the UTAUT2 framework fulfill the need of the study and is appropriate for investigating factors influencing students' behavioral intention and actual use towards e-learning tools. However, the price value construct of this revised model is thus replaced with learning value as the students do not bear any monetary costs. The proposed research model is presented in Figure 1.

This exploratory study examined students' behavioral intention to use e-learning during COVID-19 pandemics. Convenience sampling was used to collect the primary data, from students of higher educational institutions in Thailand, using a structured questionnaire. The questionnaire was a five-point Likert-scale (1=strongly disagree, 5=strongly agree), and was administered to university students through an online survey platform and shared on Facebook and Pantip.com for maximum students' participation. The data was collected between 1 June 2020 and 20 October 2020. Upon retrieval and evaluation of the responses from questionnaire and cleaning of the data, 1493 values of data was considered valid for analysis. The data was analyzed using AMOS 26, evaluating the reliability and validity of the data, and applying Structural Equation Technique (SEM) to evaluate the hypotheses of the study.

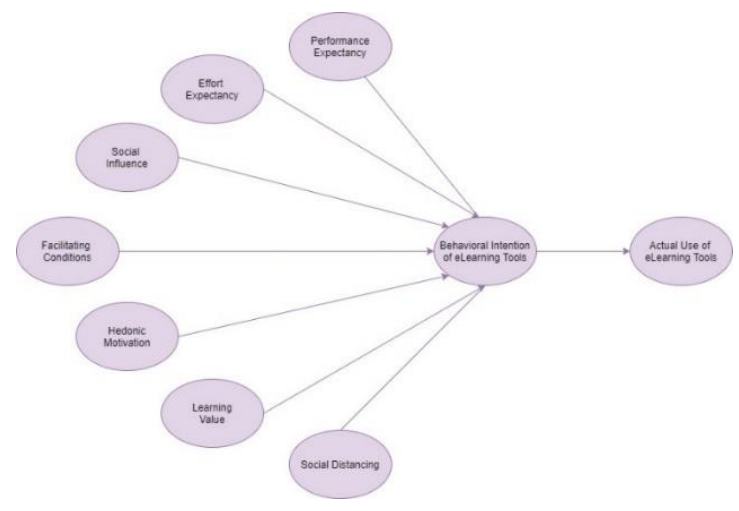

Figure 1. Conceptual framework

\section{RESULTS AND DISCUSSION}

\subsection{Preliminary analysis 1}

It was significant to evaluate the suitability of the data before conducting the actual analysis. The preliminary analysis conducted was the reliability analysis and validity analysis. AMOS 26 was applied to evaluate the reliability using Construct Reliability (CR) and validity using the Average Variance Extracted (AVE). The formulas for CR and AVE are in (1), (2). 


$$
\begin{aligned}
& A V E=\frac{\sum\left(\text { Standardized Factor Loading }{ }^{2}\right)}{\text { Number ofIndicators }} \\
& C R=\frac{\left(\sum \text { Standardied Loading }\right)^{2}}{\left(\sum \text { Standardied Loading }\right)^{2}+\sum(M E)}
\end{aligned}
$$

The results of the variables, the factor loadings, indicator, construct reliability (CR) and average variance extracted (AVE) are presented in Table 1. The figures show satisfactory results for both reliability and validity of the data and results to be obtained based on three evidences. First, all the factor loadings (estimates) are above 0.5. Secondly, all the construct reliability are above 0.6 for an exploratory research. Thirdly, all the AVE figures are above 0.5 except for the behavioral intention, hence, the conclusion that the model has the required internal consistency [49].

Table 1. Validity and reliability analysis

\begin{tabular}{lcccc}
\hline \multirow{5}{*}{ Performance expectancy } & PE3 & 0.865 & & AVE \\
& PE2 & 0.898 & & \\
& PE1 & 0.825 & 0.897521 & 0.745085 \\
Effort expectancy & EE3 & 0.852 & & \\
& EE2 & 0.802 & & \\
Social influence & EE1 & 0.764 & 0.848099 & 0.650935 \\
& SI3 & 0.808 & & \\
Facilitating condition & SI2 & 0.84 & & \\
& SI1 & 0.736 & 0.837861 & 0.633387 \\
& FC3 & 0.826 & & \\
Social distance & FC2 & 0.875 & & \\
Behavioral intention & FC1 & 0.837 & 0.88324 & 0.716157 \\
& SD2 & 0.741 & & \\
& SD1 & 0.899 & 0.807126 & 0.678641 \\
& BI1 & 0.523 & & \\
Actual use & BI2 & 0.621 & & \\
Hedonic motivation & BI3 & 0.618 & 0.613136 & 0.347031 \\
& AU1 & 0.709 & & \\
Learning value & HU2 & 0.755 & 0.698008 & 0.536353 \\
& HM1 & 0.861 & & \\
& LV2 & 0.826 & 0.831578 & 0.711799 \\
\hline
\end{tabular}

\subsection{Measurement of the model}

This section sought to evaluate the eight hypotheses of this research, using the SEM model. The hypotheses sought to evaluate the relationship that existed between the dependent and independent variables of the study, in terms of behavioral intention and actual use of the e-learning tools in the midst of COVID-19 pandemic. The results of the model are presented in the Table 2 and Figure 2.

Table 2 and Figure 2 illustrate the relationship between the endogenous variables (performance expectancy, effort expectancy, social influence, facilitating condition, hedonic motivation, learning value, social distance) with the exogenous variables (actual use, behavioral intention). The results show that the students' behavioral intention to use e-learning tools is positively and significantly influenced by performance expectancy $(\beta=0.22, p<0.05)$; effort expectancy $(\beta=0.14, p<0.05)$; social influence $(\beta=0.20$, $\mathrm{p}<0.05)$; facilitating condition $(\beta=0.50, \mathrm{p}<0.05)$; hedonic motivation $(\beta=0.35, \mathrm{p}<0.05)$; learning value $(\beta=0.51, p<0.05)$; and social distance $(\beta=0.46, p<0.05)$. similarly, behavioral intention by the students to use e-learning tools have a positive and significant effect on actual use of e-learning tools $(\beta=0.82, p<0.05)$.

\begin{tabular}{|c|c|c|c|c|c|c|}
\hline & & & Estimate & S.E. & C.R. & $\mathrm{P}$-value \\
\hline Behavioral intention & <--- & Performance expectancy & 0.102 & 0.01 & 9.67 & $* * *$ \\
\hline Behavioral intention & $<---$ & Effort expectancy & 0.063 & 0.01 & 6.268 & $* * *$ \\
\hline Behavioral intention & $<---$ & Social influence & 0.091 & 0.011 & 8.359 & $* * *$ \\
\hline Behavioral intention & $<---$ & Facilitating conditions & 0.223 & 0.014 & 16.088 & $* * *$ \\
\hline Behavioral intention & $<---$ & Hedonic motivation & 0.156 & 0.013 & 12.31 & $* * *$ \\
\hline Behavioral intention & $<---$ & Learning value & 0.232 & 0.015 & 15.196 & $* * *$ \\
\hline Behavioral intention & $<--$ & Social distance & 0.232 & 0.016 & 14.678 & $* * *$ \\
\hline Actual use & $<---$ & Behavioral intention & 1.112 & 0.067 & 16.581 & $* * *$ \\
\hline
\end{tabular}

Table 2. SEM results 


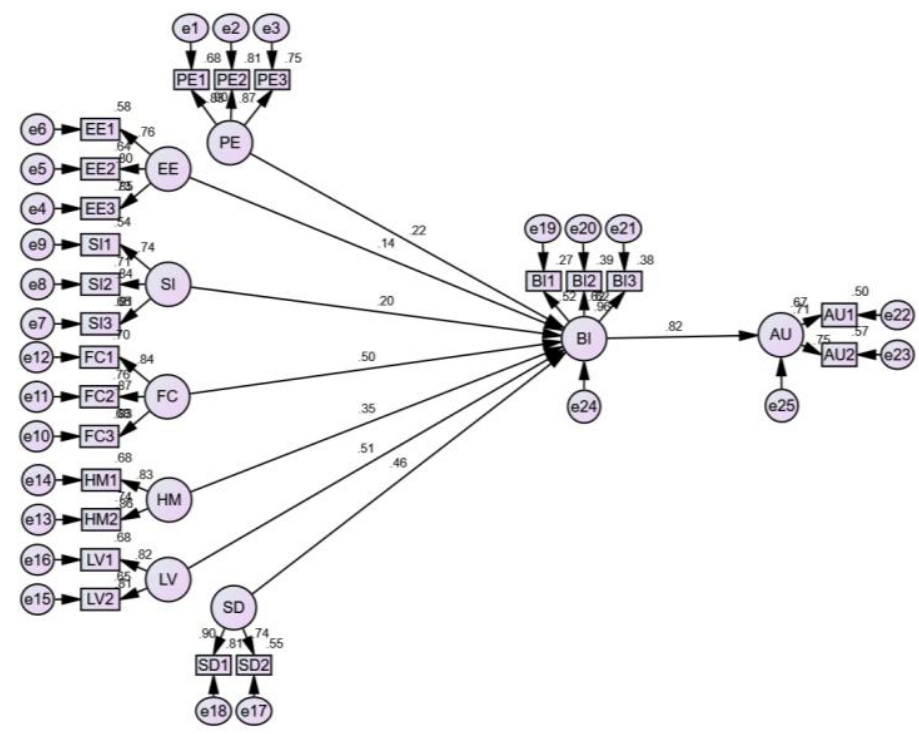

Figure 2. SEM results

Another relationship worth considering between the exogenous and endogenous variables is the direct and indirect relationship between the variables. These effects are summarized in the Table 3 . The results shows that there is a positive direct relationship between behavioral intention to use e-learning tools and performance expectancy; effort expectancy; social influence; facilitating condition; hedonic motivation; learning value; and social distance; as well as between behavioral intention and actual use. Similarly, there is a positive indirect effect between students' actual use of e-learning tools and performance expectancy; effort expectancy; social influence; facilitating condition; hedonic motivation; learning value; and social distance.

Table 3. Direct and indirect effects

\begin{tabular}{|c|c|c|c|c|c|c|c|c|}
\hline & $\begin{array}{c}\text { Learning } \\
\text { value }\end{array}$ & $\begin{array}{c}\text { Hedonic } \\
\text { motivation }\end{array}$ & $\begin{array}{c}\text { Social } \\
\text { distance }\end{array}$ & $\begin{array}{c}\text { Facilitating } \\
\text { conditions }\end{array}$ & $\begin{array}{c}\text { Social } \\
\text { Influence }\end{array}$ & $\begin{array}{c}\text { Effort } \\
\text { expectancy }\end{array}$ & $\begin{array}{c}\text { Performance } \\
\text { expectancy }\end{array}$ & $\begin{array}{c}\text { Behavioral } \\
\text { intention }\end{array}$ \\
\hline $\begin{array}{l}\text { Actual use } \\
\text { Direct effects } \\
\text { Behavioral } \\
\text { intention } \\
\text { Indirect effects }\end{array}$ & 0.51 & 0.353 & 0.46 & 0.501 & 0.197 & 0.141 & 0.224 & 0.821 \\
\hline Actual use & 0.419 & 0.29 & 0.377 & 0.411 & 0.161 & 0.116 & 0.184 & \\
\hline
\end{tabular}

The results in showing a positive and significant relationship between students' behavioral intention to use e-learning and the hypotheses measured validates the views expressed by previous studies [17], [41], indicated that students' attitude towards e-learning tools is influenced by their use of internet and other facilitating conditions. With this, students' adept and comfortable with the use of internet and web technologies will be more at ease in signing up and completing online classes compared to those not familiar with the internet and other digital technologies. Events like pandemic supported prior studies [19]-[21] that presented significant results in the adoption of behavioral intention and actual use of ICTs. In this instance, adopting ICTs in e-learning with the shutting down of traditional learning institutions, online classes have the capacity to replace in-class learning as highlighted by Hamidi and Jahanshaheefard [39] stated that some universities are delivering classes through their own personalized online learning platforms. Students can, therefore, attend lectures; submit assessments and essays like in traditional lectures thereby minimizing the impact of the disruption created by the COVID-19 pandemic. The contention by Ajzen [48] that intentions capture motivating factors and influence the use of technologies signals the willingness of users' (students) to make effort towards adoption of the technology. Once students are motivated especially with the shutting down of schools, the only available option towards completing studies with classmates at the scheduled date will serve as motivation to positively lean towards e-learning as a learning tool with similar outcomes to inclass learning.

Int J Eval \& Res Educ, Vol. 10, No. 4, December 2021: 1166 - 1175 
The findings also validated the Unified Theory of Acceptance and Use of Technology 2 (UTAUT 2) model as proposed by Venkatesh, Thong, and $\mathrm{Xu}$ [22] and follow its recommendations for additional constructs to increase its predictive power by the addition of social distancing variable in determining behavioral intention to use e-learning tools in higher educational institutions of Thailand. Kleczkowski, et al. [23] earlier discussed the importance of spontaneity of social distancing in response to the simultaneous epidemic under a virtual experiment. Measuring the impact of social distancing as a variable and motivation for behavioral use of e-learning resources is important, as health organizations around the world have talked on the ability of social distancing to reduce transmission of the virus among humans. Social distancing would serve as an important incentive not only in curtailing the spread of COVID-19, but also in allowing students continue their learning in a matter that minimizes the risk of infection to themselves or the risk of infecting others. The novelty in the findings that separates it from the previous findings is the social distancing variable. The UTAUT2 model, by this, proves its versatility of being applicable in different domains, making it possible to be deployed for academic purposes, allowing it to be used to measure the applicability and acceptability of e-learning [42], [43]. This is particular important as it demonstrates the flexibility of the model to incorporate more variables that have the capability of advancing the postulations of the theory, opening it up to new interpretations and applicability.

Some of the managerial implications developed from this study are highlighted; findings show that educational institutions are keen to discover top online learning practices which make the online learning experience extremely crucial. The findings present a detailed picture of the student's behavioral intention and actual use of e-learning tools engaged by higher educational institutions of Thailand. The institutes of higher learning should consider various aspects of e-learning tools such as those that enhance performance expectancy; effort expectancy; social influence; facilitating condition; hedonic motivation; learning value; and social distance because they influence the intention of the students to use e-learning tools, particularly during the period of COVID-19 pandemic. The study has found that e-learning tools are important strategies that ensure an uninterrupted educational curriculum, and continuously delivery of education, and at the same time allows health officials to implement measures that mitigate against the spread of COVID-19 virus. Therefore, addressing the factors that influence the e-learning tools is very important and provides an insight to guide education administrators when making policy guidelines and decisions that affect education on elearning platforms.

\section{CONCLUSION}

There has been high acclaim for e-learning tools. Numbers show students' experience difficulties getting along with technology leading to issues such as computer based anxiety, fear of technology and extremely challenging circumstances brought about by the need to conform to societal requirements in using online resources for education. This study examined the case with the lens of The Unified Theory of Acceptance and Use of Technology 2 (UTAUT2). The conceptual framework suggests that performance expectancy, effort expectancy, social influence, facilitating conditions, hedonic motivation, learning value, and social distancing of the students measured the behavior intention and actual use of students adoption of e-learning tools.

This study was conducted at higher educational institutions of Thailand. The study delivered innovation by adding social distancing to the UTAUT2 model as well as extending its application to measure students' behavioral intentions and actual use of e-learning tools. This could bring useful insights for policymakers and add to the current literature on e-learning and UTAUT2. Using Structural Equation Modelling, the study found out that students' behavioral intention to use e-learning tools is positively and significantly influenced by performance expectancy; effort expectancy; social influence; facilitating condition; hedonic motivation; learning value; and social distance. Similarly, behavioral intention by the students to use e-learning tools have a positive and significant effect on actual use of e-learning tools. Learning value was found to have the highest effect on the students' behavioral intention to use e-learning tools, followed by social distance variable. These raises the aspects of considering issues of social distance and the learning value as among the majors factors that could or are driving students towards adopting elearning tools during the COVID-19 pandemic period.

The limitations of this study are that it was conducted using seven independent variables of the UTAUT2 model, (performance expectancy, effort expectancy, social influence, facilitating conditions, hedonic motivation, and learning value), and added social distancing of the students to the list of independent variables. The study was conducted in the context of COVID-19 pandemic and in geographical area of Thailand. Therefore, the application of the findings of this study should be done with consideration to these aspects. 


\section{REFERENCES}

[1] A. Bozkurt and R. C. Sharma, "Emergency remote teaching in a time of global crisis due to Corona Virus pandemic". Asian Journal of Distance Education, vol. 15, no. 1, pp. 1-6, 2020, doi: 10.5281/zenodo.3778083.

[2] S. Chaveesuk, B. Khalid, and W. Chaiyasoonthorn, "Digital payment system innovations: A marketing perspective on intention and actual use in the retail sector," Innovative Marketing, vol. 17, no. 3, pp. 109-123, 2021, doi: 10.21511/im.17(3).2021.09.

[3] B. Khalid, S. Chaveesuk, and W. Chaiyasoonthorn, "MOOCs adoption in higher education: A management perspective," Polish J. Manage. Stud., vol. 23, no. 1, pp. 239-256, 2021, doi: 10.17512/pjms.2021.23.1.15.

[4] World Health Organization, "WHO Director-General's opening remarks at the media briefing on COVID-19 - 3 March 2020," 2020. [Online]. Available: https://www.who.int/director-general/speeches/detail/who-directorgeneral-s-opening-remarks-at-the-media-briefing-on-covid-19---3-march-2020.

[5] Number of COVID-19 cases, recoveries, deaths in most impacted countries as of May 3, 2021. Statista, 2021. [Online]. Available: https://www.statista.com/statistics/1105235/coronavirus-2019ncov-cases-recoveries-deathsmost-affected-countries-worldwide. (accessed May 3, 2021).

[6] P. Fernandez, "Coronavirus: Learning and teaching at a time of pandemic," Gulf News, 2020. [Online]. Available: https://gulfnews.com/opinion/op-eds/coronavirus-learning-and-teaching-at-a-time-of-pandemic-1.70612656

[7] A. Hariharasudan, and S. Kot, "A Scoping Review on Digital English and Education 4.0 for Industry 4.0," Social Sciences, vol. 7, no. 11, p. 227, 2018, doi: 10.3390/socsci7110227.

[8] B. Khalid, M. Lis, W. Chaiyasoonthorn, and S. Chaveesuk, "Factors influencing behavioural intention to use MOOCs," Eng. Manage. Prod. Services, vol. 13, no. 2, pp. 83-95, 2021, doi: 10.2478/emj-2021-0014.

[9] M. Lis, "Higher Education Institutions as Partners in Growing Innovation of Local Economy," Social Sciences, vol. 10, no. 8, p. 316, 2021, doi: 10.3390/socsci10080316.

[10] A. Chavoshi and H. Hamidi, "Social, individual, technological and pedagogical factors influencing mobile learning acceptance in higher education: A case from Iran," Telematics and Informatics, vol. 38, pp. 133-165. 2019, doi: 10.1016/j.tele.2018.09.007.

[11] S. Sarbaini, J. Jumadi, E. Abbas, and I. Rajiani, "Managing e-learning in public universities by investigating the role of culture," Polish J. Manage. Stud., vol. 20, no. 1, pp. 394-404, 2019, doi: 10.17512/pjms.2019.20.1.34.

[12] R. Stefko, R. Fedorko, and R. Bacik, "Website content quality in terms of perceived image of higher education institution," Polish J. Manage. Stud., vol. 13, no. 2, pp. 153-163, 2016, doi: 10.17512/pjms.2016.13.2.15.

[13] M. M. Stuss, K. Szczepańska-Woszczyna, and Z. J. Makieła, "Competences of graduates of higher education business studies in labor market (Results of pilot cross-border research project in Poland and Slovakia)," Sustainability, vol. 11, no. 18, p. 4988, 2019, doi: 10.3390/su11184988.

[14] I. Im, S. Hong, and M. S. Kang, "An international comparison of technology adoption," Information \& Management, vol. 48, no. 1, pp. 1-8, 2011, doi: 10.1016/j.im.2010.09.001.

[15] R.-L. Hsiao, "Technology fears: distrust and cultural persistence in electronic marketplace adoption," The Journal of Strategic Information Systems, vol. 12, no. 3, pp. 169-199, 2003, doi: 10.1016/s0963-8687(03)00034-9.

[16] W.-H. D. Huang, D. W. Hood, and S. J. Yoo, "Gender divide and acceptance of collaborative Web 2.0 applications for learning in higher education," The Internet and Higher Education, vol. 16, pp. 57-65, 2013, doi: 10.1016/j.iheduc.2012.02.001.

[17] Indrawati and M. N. Has, "Examining factors influencing webinar adoption using UTAUT model (Case study at distance learning program, ABC University, Bandung-Indonesia 2016)," 2016 IEEE Asia Pacific Conference on Wireless and Mobile (APWiMob), 2016, pp. 52-58, doi: 10.1109/APWiMob.2016.7811434.

[18] A. I. Saroia and S. Gao, "Investigating university students' intention to use mobile learning management systems in Sweden," Innovations in Education and Teaching International, vol. 56, no. 5, pp. 569-580, 2018, doi: 10.1080/14703297.2018.1557068.

[19] M. A. Yeop, M. F. M. Yaakob, K. T. Wong, Y. Don, and F. M. Zain, "Implementation of ICT Policy (Blended Learning Approach): Investigating factors of Behavioural Intention and Use Behaviour," International Journal of Instruction, vol. 12, no. 1, pp.767-782, 2019. [Online]. Available: https://files.eric.ed.gov/fulltext/EJ1201344.pdf.

[20] T. H. Tseng, S. Lin, Y.-S. Wang, and H.-X. Liu, 'Investigating teachers' adoption of MOOCs: the perspective of UTAUT2," Interactive Learning Environments, pp. 1-16, 2019, doi: 10.1080/10494820.2019.1674888.

[21] M. Z. Solesvik, "Entrepreneurial competencies and intentions: the role of higher education," Forum Scientiae Oeconomia, vol. 7, no. 1, pp. 9-23, 2019, doi: 10.23762/FSO_VOL7_NO1_1.

[22] V. Venkatesh, J. Thong, and X. Xu, "Consumer Acceptance and Use of Information Technology: Extending the Unified Theory of Acceptance and Use of Technology," MIS Quarterly, vol. 36, no. 1, pp. 157-178, 2012, doi: $10.2307 / 41410412$.

[23] A. Kleczkowski, S. Maharaj, S. Rasmussen, L. Williams, and N. Cairns, "Spontaneous social distancing in response to a simulated epidemic: a virtual experiment," BMC Public Health, vol. 15, no. 1, pp. 1-13, 2015, doi: 10.1186/s12889-015-2336-7.

[24] N. Meekaewkunchorn, K. Szczepańska-Woszczyna, C. Muangmee, N. Kassakorn, and B. Khalid, "Entrepreneurial orientation and SME performance: The mediating role of learning orientation," Economics \& Sociology, vol. 14, no. 2, pp. 294-312, 2021.

[25] C. Muangmee, S. Kot, N. Meekaewkunchorn, N. Kassakorn, and B. Khalid, "Factors determining the behavioral intention of using food delivery apps during COVID-19 pandemics," Journal of Theoretical and Applied Electronic Commerce Research, vol. 16, no. 5, pp. 1297-1310, 2021, doi: 10.3390/jtaer16050073. 
[26] C. Muangmee, Z. Dacko-Pikiewicz, N. Meekaewkunchorn, N. Kassakorn, and B. Khalid, "Green entrepreneurial orientation and green innovation in Small and Medium-Sized Enterprises (SMEs)," Social Sciences, vol. 10, no. 4, p. 136, 2021, doi: 10.3390/socsci10040136.

[27] W. P. Wall, B. Khalid, M. Urbański, and M. Kot, "Factors influencing consumer's adoption of renewable energy," Energies, vol. 14, no. 17, pp. 5420, 2021, doi: 10.3390/en14175420.

[28] S.A. Fazal, A. Al Mamun, S.A. Wahab, and M. Mohiuddin, "Social and environmental sustainability, host country characteristics, and the mediating effect of improved working practices: Evidence from multinational corporations in Malaysia," Journal of Asia-Pacific Business, vol. 20, no. 2, pp. 102-124, 2019, doi: 10.1080/10599231.2019.1610683.

[29] B. Khalid and M. Kot, "The impact of accounting information systems on performance management in the banking sector," IBIMA Business Review, vol. 2021, Article ID 578902, pp. 1-15, 2021, doi: 10.5171/2021.578902.

[30] S. Chaveesuk, B. Khalid, and W. Chaiyasoonthorn, "Emergence of New Business Environment with Big Data and Artificial Intelligence," Proceedings of the 9th International Conference on Information Communication and Management (ICICM), 2019, doi: 10.1145/3357419.3357441.

[31] A.U. Haque, B. Basuki, J. Aston, and R. Widyanti, "Do different stressors affect working efficiency of public university personnel differently?" Polish J. Manage. Stud., vol. 23, no. 1, pp. 172-187, 2021, doi: 10.17512/pjms.2021.23.1.11.

[32] C.-S. Yu, "Factors Affecting Individuals to Adopt Mobile Banking: Empirical Evidence from the UTAUT Model," J. Electron. Commerce Res., vol. 13, no. 2, pp. 104-121, 2012. [Online]. Available: http://www.jecr.org/node/48.

[33] M. K. Keles and S. A. Özel, A Review of Distance Learning and Learning Management Systems. IntechOpen, 2016, doi: 10.5772/65222.

[34] M. Simonson and G. A. Berg, "Distance learning," Encyclopedia Britannica, Nov. 2016. [Online]. Available: https://www.britannica.com/topic/distance-learning.

[35] S. Bauk and J. Jusufranic, "Competitiveness in Higher Education in Terms of the Level of Students' Satisfaction with e-Learning in Blended Environment," Montenegrin Journal of Economics, vol. 10, no. 1, pp. 25-42, 2014. [Online]. Available: http://www.repec.mnje.com/mje/2014/v10-n01/mje_2014_v10-n01-a13.pdf.

[36] R. Holzmann and S. Jørgensen, "Social risk management: A new conceptual framework for social protection and beyond," International Tax and Public Finance, vol. 8, no. 4, pp. 529-556, 2001, doi: 10.1023/a:1011247814590.

[37] Z. Liu, X. Bing, and X. Z. Zhi, "The epidemiological characteristics of an outbreak of 2019 novel coronavirus diseases (COVID-19) in China," National Library of Medicine, vol. 41, no. 2, pp. 145-151, 2020, doi: 10.3760/cma.j.issn.0254-6450.2020.02.003.

[38] M. Fishbein and I. Ajzen, Belief, Attitude, Intention, and Behavior: An Introduction to Theory and Research, 1st ed. Addison-Wesley, 1975

[39] H. Hamidi and M. Jahanshaheefard, "Essential factors for the application of education information system using mobile learning: A case study of students of the university of technology," Telematics and Informatics, vol. 38, pp. 207-224, May 2019, doi: 10.1016/j.tele.2018.10.002.

[40] S. M Lemon, M. A. Hamburg, P. F. Sparling, E. R. Choffnes, and R. A. Mack, Ethical and legal considerations in mitigating pandemic disease, 1st ed. Washington, DC: The National Academies Press, 2007, doi: 10.17226/11917.

[41] F. Kanwal and M. Rehman, "Factors Affecting E-Learning Adoption in Developing Countries-Empirical Evidence from Pakistan's Higher Education Sector," IEEE Access, vol. 5, pp. 10968-10978, 2017, doi: 10.1109/ACCESS.2017.2714379.

[42] G. Dağhan and B. Akkoyunlu, "Modeling the continuance usage intention of online learning environments," Computers in Human Behavior, vol. 60, pp. 198-211, 2016, doi: 10.1016/j.chb.2016.02.066.

[43] F. Zhang, E. W. Welch, and Q. Miao, "Public Organization Adaptation to Extreme Events: Mediating Role of Risk Perception," Journal of Public Administration Research and Theory, vol. 28, no. 3, pp. 371-387, 2018, doi: 10.1093/jopart/muy004.

[44] N. Lung-Guang, "Decision-making determinants of students participating in MOOCs: Merging the theory of planned behavior and self-regulated learning model," Computers \& Education, vol. 134, pp. 50-62, 2019, doi: 10.1016/j.compedu.2019.02.004.

[45] C. Peechapol, J. Na-Songkhla, S. Sujiva, and A. Luangsodsai, "An Exploration of Factors Influencing SelfEfficacy in Online Learning: A Systematic Review," International Journal of Emerging Technologies in Learning (IJET), vol. 13, no. 9, pp. 64-86, 2018, doi: 10.3991/ijet.v13i09.8351.

[46] K.-Y. Lin, C.-P. Kao, and H.-M. Chien, "Predicting Teachers' Behavioral Intentions Regarding Web-based Professional Development by the Theory of Planned Behavior," EURASIA Journal of Mathematics, Science and Technology Education, vol. 14, no. 5, pp. 1887-1896, 2018, doi: 10.29333/ejmste/85425.

[47] J. Ejdys, "Factors affecting the adoption of e-learning at university level," WSEAS Transactions on Business and Economics, vol. 18, pp. 313-323, 2021, doi: 10.37394/23207.2021.18.32.

[48] I. Ajzen, "The theory of planned behavior," Organizational Behavior and Human Decision Processes, vol. 50, no. 2, pp. 179-211, 1991, doi: 10.1016/0749-5978(91)90020-t.

[49] J. F. Hair, W. C. Black, B. J. Babin, and R. E. Anderson, Multivariate Data Analysis. Prentice Hall, 2010. 